\title{
Semiotics of culture and New Polish Ethnology
}

\author{
Marcin Brocki \\ Dept. of Ethnology, University of Wroclaw \\ Koszarowa 3, 51-149 Wroclaw, Poland \\ e-mail: mbrocki@magma-net.pl
}

\begin{abstract}
The paper deals with the contemporary state of semiotic ethnology in Poland (connected with New Polish Ethnology group), its internal and external influences, its specifics, subjects and its reaction to the other theoretical propositions. The "neotribe" of New Polish Ethnology was established by few younger scholars, ethnologists in the early 1980s, in an opposition to the dominant stream of positivistic ethnology. Today they have become classics of Polish anthropology, masters that have educated a new generation of their students, and lead some anthropological institutes. The most inspiring set of theories that influenced the group and its heirs was taken from Soviet semiotics of culture (Lotman, Uspensky, Toporov, Ivanov), and French structural-semiotics (Levi-Strauss, Barthes), but there are some individual differences also. On that basis they have developed a specific scope, aim and methods of interpretation with as its key terms myth and mythical thinking. They have explained many cultural events (relation we-others, body image, commercials, and anthropology itself) within the framework of mythical thinking, making it the most productive and attractive frame of interpretation within Polish humanities and social sciences. In the 1990s they had to face critical ethnography, deconstruction and postmodern anthropology and they did it with perfect flexibility that even strengthened their project, because the potential of reflexivity and self-consciousness lied within semiotics from its beginning.
\end{abstract}

Contemporary Polish ethnology is divided into theoretical and thematic monads or into rather different styles of doing ethnography, because we are dealing here more with styles of thinking than with rigorously delineated methodological orientations (a situation well known in the humanities generally). We are dealing with attachments to some traditions of thinking and ways of understanding the weight 
and place of fieldwork in the scholarly practice (here the difference between realism and reflexivity comes to the fore), to the style of interpretation and explanation of the cultural phenomena, as well as to the circle of people sharing the views on the ways anthropology should be done.

I have to make a short remark that is necessary for understanding the core of the New Polish Ethnology (NPE, the Polish abbreviation is NEP — sounds like Novaja Ekonomiczeskaja Politika, and in the context I will talk about it is, I suppose, of some significance). Until the mid-1970s Polish ethnology was dominated by the modernist or positivist research paradigm within which the role of ethnography was reduced to mere recording and describing of the data, especially to describing observable changes in the folk culture. In the context of the political system then in power, the so-called "people's democracy", the pressure was to valorize folk culture as the storage and carrier of truly human and national content (Buchowski 1995). At the same time ethnography was understood as a science of an unmediated experiencing of material, social and spiritual phenomena, where direct observation and informants' "testimonies" gave crucial evidence to the authenticity of facts, that were "only described", as it was believed, facts.

A group of younger scholars started to fight against this official trend at the turn of the 1970s and 1980s. They were affiliated with structuralism, semiotics of culture and phenomenology. They called their "neo-tribe" New Polish Ethnology and the group remains the most interesting, unique and inspiring phenomenon in Polish ethnology to date. The term "neo-tribe" is not coincidental here - I use it because it means a voluntary belonging, flow of members, relative ephemerality of shared views, no rigorous power centre, in general, it is the most suitable term to characterize the cohesiveness of the group (Buchowski 1995).

There have been two directions within the NPE: (1) structuralsemiotic, and (2) phenomenological-hermeneutic; the first one (which is at the same time the subject of my presentation) stresses especially the mytho-logical nature of thinking and the role it plays in everyday life and history; it refers to the theoretical traditions of French structuralism and semiotics (Levi-Strauss, Barthes, New History), British structural anthropology (Leach, Douglas, Turner) and to the semiotics 
of culture developed by the Tartu School (Lotman, Uspensky, Toporov, Ivanov, Piatigorskij and others). ${ }^{1}$

Scholars involved in this coup d'etat took over the leadership of Polish ethnology, becoming not only chairs of academic institutes but also classics of contemporary Polish ethnology.

We can read in the programme manifesto of this group from the beginning of the 1980 s that these scholars:

1. Abandon positivistic and post-positivistic orientation in ethnology in favour of systemic depictions derived from the native categories of thinking and not imposed by the cognitive/research methods of the researcher.

2. Will use a coherent and consistent conceptual and methodological apparatus which emphasizes the semantic aspects (significance) of cultural phenomena.

3. Will aim in their research at the so-called mental culture system (ritual, religion, mythology, folk literature, problems of cultural identity etc.), because they assumed that it is in the domain of the mentality, "spirit", in the ideational sphere of culture mechanisms determining cultural phenomena and behaviour should be sought.

4. Will give up contingent descriptions of cultural phenomena, so far exerted by formal pseudo-classification (disassociated from the way culture is classified by its members), and will concentrate instead on synthesizing and interpretive works, aimed at unravelling the structures of long duree (regardless of the fact whether they exist in reality, they do become manifest as common rules in culture), the grammar of culture - a base set of oppositions on which cultural practice is built (this grammar for Polish 19th century folk culture was reconstructed by Ludwik Stomma).

5. Advocated interdisciplinarity conceived as multi-sided use and assimilation of contemporary achievement of related disciplines, especially history, semiotics, sociology of religion, linguistics and literary studies. (Benedyktowicz et al. 1980-1981: 47)

Nowadays they underline the interpretive (description = interpretation) character of ethnologist's work - which means, among other things, that an ethnologist does not only work with the text of culture, but also that they realize the fact an ethnologist constructs his own data (carries out a semiosis of the examined culture) with the help of his own cultural tools, including those provided by professional/expert anthropological knowledge. As a result, ethnology emerges as a kind

1 We can enumerate here members of the group and their heirs: Zbigniew Libera, Małgorzata Maj, Krzysztof Piatkowski, Czeslaw Robotycki, Ludwik Stomma, Ryszard Tomicki, Jerzy Wasilewski. 
of cultural criticism (it is not axiologically neutral), but, in contrast to American scholars, the scholars from the semiotic ethnology group do not fetishize this fact, which means, they do not yield to "moral hypochondria" (according to Geertz's or D'Andrade's formulation) whose main symptom is that the author is more engaged in the "writing self" than he is in what was supposed to be the proper object of research and interpretation.

"Ethnography of ethnography" is for them solely a necessary element of an epistemological debate within the discipline and it does not obfuscate research. For example, Libera comes near "ethnography of ethnography" in his research on cultural taboos connected with "the bottom". The subject seemed inappropriate to such an extent that it was guarded off by a unique inner censorship eliminating from research all topics considered "inelegant". The process was based in fact on a mechanism of projecting the obvious in one's own culture onto the language of ethnology, without an awareness that this is being done.

The group is interested mainly in contemporary phenomena, among others in popular culture which uses mythic structures of thinking to reinforce its power of persuasion, and in the way it functions in the collective common consciousness (in advertising, film, popular literature, literature for children, school manuals, music and architecture, for example). However, they also do stimulating research on folk medicine, body as a social and cultural construct, gesture, history as the area of continuous semiosis, as well as the mythicized consciousness of ethnology itself. Their object of investigation is, among others, the way norms and stances are entangled in worldviews and beliefs; the cosmological and ritual vision of the universe; cultural mythicizing in the self-other relations (here the research on AIDS, old age and illness joined a more traditional discourse on local and national difference); as well as the problem of stereotyping and mythicizing of culture itself, a process which involves both people who deal with culture as amateurs, as well as professionals (museums, academic institutions) (Robotycki 1995: 231-232).

Methodological directives recognized by the group largely derive from all the structural and semiotic traditions mentioned above: (1) translation of culture by culture (Libera 1995b: 17) leads to the search for an inner logic of culture; This logic, however, once discovered, often serves as a subsequent justification of theses assumed in the 
work or explanations developed (Libera 1995b: 18); (2) they keep underlining the classificational and descriptive character of the natural language, that is why linguistic data still play an important role in their research, especially data concerning semantics, as they allow for the reconstruction of cultural classificational schemes and of the social function of phenomena investigated.

At present they do not, however, get attached to the notion of the primary and secondary semiotic systems and their work is developed more in the spirit of Lotman's "semiosphere", though none of them mention the fact. But, on the other hand, they assume in a series of texts on the body (Libera, Brocki), especially concerning the problem of the body as a microcosm, after Toporov and Zoltariev, that in the relationship between human being and the world, man and human body still remains the modelling factor.

They also creatively approached the base concept of text and myth developed by semiotics of culture. In his newest work Czesław Robotycki revises, under the influence of deconstruction, the concept of the text of culture substituting it for the concept of narration. The reason behind this substitution is very straightforward: the other term is more suggestive of a situation in which "the world does not try to tell us anything", it is a narration without any objective frames which would limit its reach (which is the case of the text). Such frames are culture's artefacts. As Robotycki writes: "This is us who endow history with sense" (Robotycki 1998: 11), and the word "history" can be exchanged for anything yielding to the process of semiosis. Apart from this, the term text becomes a platitude, exploited and abused in so many contexts that we have difficulties in recognizing it as text. It turns into an intellectual fetish in these contexts - the best example to quote is my friend's dedication to his book on reflexive anthropology, which reads: "To my wife, who is reality, reflection, and text".

The concept of myth and mythic thinking is similarly undergoing modification at the moment, although it still remains a universal explanatory category, the most efficient interpretive tool of a wide range of cultural phenomena, a category belonging to the realm of certitudes within professional anthropological culture. Ludwik Stomma remains the keenest advocate in Poland of Roland Barthes' thesis that "myth is stronger than facts" or that "myth strives to accord with sense and not with sensually conceived reality", and Zbigniew Libera (1995a: 11), in contrast, modifies this thesis in his writings on folk medicine and anthropology. Stomma writes that "products of 
mythicization neither refer to reality, nor can reality verify them", "the empirical has an inferior significance than myth and has to give way to it", and he indeed quotes examples proving his theses. Libera, in turn, shows on the example of "folk medicine" that the efficiency of many medical interventions is not a pure coincidence, as Stomma's thesis about the priority of logic (abstracted out of the everyday life praxis) over praxis would imply, but has also its own empirical source. Medicine cannot be reduced to myth, because the experiments of myth are not the same as experiments of folk medicine, as the latter do not happen in the abstracted space of purely intellectual operations. If this were so, one could treat any illness with any means, as long as it conformed to the requirements of the logic. He postulates inclusion of relations of practice and convictions from the range of a discernible semantic cultural domain (here Libera remains faithful to the concept of the "text of culture") with the simultaneous recognition of their mytho-logical basis, so that the field is seen as an element of a larger, sense-endowed and coherent whole, which comes down to, basically, the world view of a given collectivity (it resembles Bourdieu's theory of practice, but Libera developed it independently). This allows, in turn, to put forth a thesis that diverse texts of culture realize the same paradigm of sense, that they have the same storage of meanings, which, however, does not simultaneously mean that semiotic systems are synonymous, as they always retain a certain level of autonomy (Libera 1995a: 12).

The principle that remains unchanged in the concept of myth says that myth involves substituting the order of nature for the order of culture - showing social, ideological, historical products as natural etc. - and, on the other hand, representing direct products of cultural and social relations and moral, aesthetic, class, ideological problems as emerging out of themselves, naturally, which, in turn, leads to their recognition as "good laws", "the voice of the public", "norms", "laudable principles" — as inborn, necessary givens (Stomma, in: Benedyktowicz et al.: 48). On the basis of this definition of myth Polish semiotic ethnology still carries out efficient interpretations of many complex phenomena of contemporary culture (for example: advertising, political, economic, historical and scientific discourses). The NEP ethnologists, pointing at the symbolic character of culture, diverse ways of conveying semiosis (history, tradition, local and regional identities etc.) and antinomies emerging in the process, antinomies which are always present and always overcome, not only 
represent semiosis as a continuous process not knowing a simple reproduction of patterns, but they also find the main source of overcoming and reducing the unlimited potential of semiosis in myth itself. A member of culture dealing with texts inviting various readings tries to neutralize (or mask) the effect of paradox by mythicization of reality. An anthropologist, in turn, demythicizing this text (an objective of semiotic anthropology that, for the NEP, equals with unravelling the rules governing a given text of culture), recodes the content of mythicized fragments of culture into the terms of his own practice, within the frames of professional anthropological culture. Here we can see the symptoms of the "moral hypochondria" mentioned above, which is immediately reshaped under the auspices of the NEP into an element of control for the current practice. Scholars from this circle do not share the modernist or positivist view contained implicitly in the "moral hypersensitivity" that translation is to reflect and copy the original; quite the reverse - it has to reshape and deform in order to make possible the understanding of what the object of translation is. One can only reconcile with it and go on with interpretation. Otherwise we would be sentenced to an incapacitating moral anxiety paralyzing all action, or to the restoration of myth of "science as the mirror of nature", even worse - we would abolish the distance between the researched and the researcher, the very fundamental division of anthropological knowledge. But, so far, the NEP people do not manifest any suicidal tendencies.

\section{References}

Benedyktowicz, Zbigniew; Robotycki, Czesław; Stomma, Ludwik; Tomicki, Ryszard; Wasilewski, Jerzy S. 1980-1981. Antropologia kultury w Polsce dziedzictwo, pojęcia, inspiracje. Materiały do słownika. Polska Sztuka Ludowa 34(1-2): 35(1).

Buchowski, Michał 1995. Fratrie i klany nowo-plemienia antropologow w Polsce. In: Posern-Zieliński, Aleksander (ed.), Etnologia Polska. Miedzy ludoznawstwem a antropologia. Poznan: Wydawnictwo Drawa, 37-60.

Libera, Zbigniew 1995a. Medycyna ludowa. Chlopski rozsadek czy gminna fantazja? Wroclaw: Wydawnictwo Uniwersytetu Wroclawskiego.

- 1995b. Rzyc, aby zyc. Tarnow: Liber Novum.

Robotycki, Czesław 1995. Antropologia kultury w Polsce - projekt urzeczywistniony. Lud 78: 227-243.

- 1998. Nie wszystko jest oczywiste. Krakow: Wydawnictwo Uniwersytetu Jagiellonskiego. 


\section{Семиотика культуры и новая польская этнология}

Статья посвящена современному состоянию семиотической этнологии в Польше (связанной с группой Новая польская этнология New Polish Ethnology), еe внутренним и внешним влияниям, eе специфике, ее представителям и ее реакции на иные теоретические положения. Группа New Polish Ethnology была основана в начале 1980-х годов молодыми этнологами в качестве оппозиционной по отношению к доминирующему течению позитивистской этнологии. К настоящему времени они стали классиками польской антропологии, которые обучили новое поколение польских этнологов и руководят несколькими институтами антропологии. Наибольшее влияние на группу и ее последователей оказали такие теории, как семиотика культуры Тартуско-Московской школы (Лотман, Успенский, Топоров, Иванов) и французский структурализм (ЛевиСтросс, Барт). На этой теоретической основе они выработали свой, специфический угол зрения, поставили свои цели и развили собственные методы интерпретации, используя термины “текст”, "миф" и "мифологическое мышление" в качестве ключевых. Они объясняли явления культуры, на первый взгляд находящиеся далеко друг от друга (как, например, отношение “мы - другие”, имидж тела, реклама, сама антропология), в рамках мифологического мышления, создавая таким образом самую продуктивную и атрактивную интерпретационную систему в польской гуманитарной и социальной науках. В 90-е годы, противостоя натиску критической этнографии, деконструкции и постмодернистской антропологии, они выстояли и даже укрепили свой проект, поскольку потенциал рефлективности и самосознания уже был заложен в той семиотике, с которой они «стартовали».

\section{Kultuurisemiootika ja uus poola etnoloogia}

Vaatluse all on semiootilise etnoloogia olukord tänapäeva Poolas (seotud rühmitusega Uus Poola Etnoloogia/New Polish Ethnology), selle sisemised ja välised mõjutajad, eripära ja reaktsioon teistele teoreetilistele seisukohtadele. Rühmituse New Polish Ethnology asutasid 1980ndate alguses noored etnoloogid vastukaaluks positivistliku etnoloogia domineerimisele Poolas. Tänapäeval on neist saanud poola antropoloogia klassikud, kes on välja õpetanud uue põlvkonna ja juhivad mitut antropoloogia instituuti. Teooriatest mõjutasid seda gruppi kõige enam TartuMoskva kultuurisemiootika (Lotman, Uspenski, Todorov, Ivanov) ja 
prantsuse strukturalism (Levi-Strauss, Barthes). Sellel teoreetilisel baasil arendasid nad välja oma, eripärase vaatenurga, oma eesmärgid ja tõlgendamismeetodid koos võtmeterminitega — "tekst", "müüt" ja "müütiline mõtlemine". Nad seletasid kultuurinähtusi (esmapilgul justkui üksteisest eemalasuvaid, nagu "meie-teised" suhe, keha imago, reklaam, antropoloogia ise) müütilise mõtlemise raamistikus, luues nii kõige produktiivsema ja atraktiivsema interpretatsioonisüsteemi poola humanitaar- ja sotsiaalteadustes. 90ndatel, seistes vastu kriitilise etnograafia, dekonstruktsiooni ja postmodernse antropoloogia survele, jäid nad püsima ja isegi tugevdasid oma projekti, kuna refleksiivsuse ja eneseteadlikkuse potentsiaal oli juba olemas selles semiootikas, kust nad alustasid. 